\title{
Bad Queen Bess? Libels, Secret Histories, and the Politics of Publicity in the Reign of Queen Elizabeth I
}

Review Number: 2083

Publish date: Thursday, 16 March, 2017

Author: Peter Lake

ISBN: 9780198753995

Date of Publication: 2016

Price: $£ 35.00$

Pages: 512pp.

Publisher: Oxford University Press

Publisher url: https://global.oup.com/academic/product/bad-queen-bess-9780198753995?cc=gb\&lang=en\& Place of Publication: Oxford

Reviewer: Andrew Hadfield

Every mode of writing history has its attendant dangers. The problem with so much conventional political and religious history is that it is an attempt to explain what actually happened. This seems sensible enough, of course, but it inevitably privileges the ways in which the successful historical actors valued their actions, as well as almost inevitably concentrating on an elite. Of course, now that we no longer believe in the triumph of Protestantism and recognise that most 16th-century Englishmen and women were confused, bemused, terrified and/or Catholic, the story of the Reformation has become much more interesting and much sadder and so requires a different approach in order to tell a different story.

When thinking about post-Reformation England, the question we need to ask is whether we have gone far enough in acknowledging the opinions and arguments of the defeated, their hopes for regime change, desire to foster effective resistance, and mistaken belief that eventually they would triumph. The task is not simply to assemble a mass of documents detailing the arguments and beliefs of a particular faction which has slipped under our radar. Rather, we need to reconstruct and rethink how debate and argument took place, and engage with the nature of a public sphere that was confusing, often inchoate and not always understood well by those who participated in it. Sometimes things are not quite what they seem and particular arguments have become disguised and displaced.

Peter Lake's substantial new book, Bad Queen Bess?, continues his lifelong labour of making sense of the complex legacy of post-Reformation thought in England. In analysing the wealth of polemical literature of the second half of Elizabeth's reign he is continuing both his early work, Moderate Puritans and the Elizabethan Church, and his more recent attempts to think about murder pamphlets and religion in The AntiChrist's Lewd Hat. In this new project, based on his Ford lectures of 2010-11, but really dating back to 2001, Professor Lake sets himself the task of analysing the nature of 'Catholic polemical commentary on Elizabethan politics' (p. 1). The claim is that we cannot really understand late Elizabethan political culture if we fail to grasp that 'various initiatives undertaken by the state ... can only properly be understood when they are set in a tensely dialogic relationship with what certain Catholic ideologues were doing and saying' (p. 7). The book, following the expanded lectures, has seven sections. The first has three chapters on the debates surrounding Mary Stuart; the second three chapters on the debates about Catholic loyalism in the 
wake of the projected Anjou match; the third, three chapters on William Cecil, Lord Burghley's attempt to establish the principal of monarchical republicanism should the queen die without establishing a secure Protestant succession; the fourth two chapters detailing the interactions between English and French politics, specifically the fear that papal interference and consequent civil war could cross the channel; the fifth two chapters on failed attempts at regicide, its reasons, consequences and aftermath; the sixth two chapters on the return to debates about evil counsel in the 1590s; and the final section two chapters on a more confident government on the attack in the late 1590s cunningly sowing chaos through underhand tactics.

Professor Lake's approach throughout Bad Queen Bess? is to show how closely pamphlets resembled each other in substance, style and argument, a labour of careful close-reading which is designed to reveal how exchanges in the public world of the printed book determined the nature of political thought in the period. The opening chapter analyses Thomas Norton's official government response to the proposed match between Thomas Howard, fourth Duke of Norfolk, and Mary Stuart, A warning against the dangerous practises of papists, published by John Day who also published Foxe's Acts and Monuments, in conjunction with an anonymous Catholic response, An answer to a slanderous book called a discourse touching the pretended match between the duke of Norfolk and the queen of Scots. The duke had claimed at his trial that he had planned to marry the Scottish queen as an act of great patriotism to cement Anglo-Scottish relations, not out of a desire for the throne, and it was never clear whether he had been set up; acted as part of a wider conspiracy; or just been a bit silly. Professor Lake deftly shows an event shrouded in uncertainty and rumour was then used by each side to accuse the other of generating a smokescreen to disguise what they were really up to:

Each side thus cited the other's activities as a licence for their own. In particular, each cited the other's side resort to various sorts of appeals to the public or opinion in order to justify their own equally libellous, malign, and illegitimate resort to the same claims and methods. Quite remarkable is the eerie resemblance between each side's account of the other's sinister manipulation of news and rumour and of the nature of the arena of discourse and debate, of rumour and opinion, to which both were appealing and indeed seeking to bend their own version of events (p. 37).

The passage is worth quoting at length because it represents what is at the heart of Bad Queen Bess?: meticulous attention to the language of apparently mundane works which shows how each side was starting to realise the impact that printed matter could have on wider opinion. As Professor Lake points out soon afterwards, Norton was hardly being dispassionate in his analysis, but was obviously 'appealing to a wider public or series of publics in order to put pressure back on the queen' (p. 39). Indeed, Elizabeth was caught in a terrible position forced to choose between 'two mutually exclusive libellous histories' (p. 55).

Of course, such analysis will not come as a vast surprise to many literary critics and historians working on the 1590s: after all, it is what we know Edmund Spenser did in the second edition of The Faerie Queene and we also know that Burghley carefully orchestrated a campaign to force Elizabeth to have Mary executed. What is new here is the attempt to create a larger picture of political culture, one in which each side realised that it was in their interests to create a clear picture of right and wrong, in which they were the honest and straightforward supporters of justice whose decent truthfulness was obscured by the Machiavellian tactics of the opposition who claimed vast support when they were really a tiny, self-interested cabal. Put another way, the game was to persuade readers that in a time of confusion sown by dishonest practice on a grand scale, one had to keep the faith and stick together. Success depended, paradoxically, on repeatedly emphasising that this was a time of deceit and trusting that the reader could be persuaded (or flattered) into choosing the right path. The more pamphlets created the sense that there really was a world of chaos outside the more they were likely to be read as the only way to escape from it.

The truth is that in an uncertain world no one really knew the truth about peoples' real religious allegiances. We still do not know how many people were really Catholic and how many really Protestant, or if, indeed, 
they knew themselves, or if it was a meaningful distinction for many. As Professor Lake points out later on, the dream of government rhetoric was that they could eventually find a way to identify and remove the disloyal and leave the country populated only by loyal supporters, a goal they knew was impossible for all their claims and indignant claims to be the only side telling the truth. It was 'a fantasy whereby, through some cunning wheeze or another, the regime might be able both to identify its really reliable supporters and/or to flush into the open its really dangerous enemies' (p. 333). The carefully prepared 'Scottified' translation of George Buchanan's assault on Mary Stuart has been believed by many ever since but it was 'a tissue of lies and absurdities, and popular rumour' (p. 47), and part of a more concerted campaign by Burghley to plant works endorsing his ideas in the public realm as though they had appeared by public demand (which did not prevent Burghley from denouncing his opponents for allegedly similar tactics (p. 431)). Ane Detection was answered by John Leslie's Defence of the honour of the right high, mighty and noble princess Mary, which was 'an attempt to render Mary Stuart not merely innocent of any crime but the epitome of monarchical legitimacy and the personification of moral and political order in both Scotland and England' (p. 50). The debate has continued in varying forms ever since.

One of the key tropes which both sides developed was that of the bad counsellor, the evil-minded voice close to the monarch who infected the body politic by leading the ruler astray through malicious lies, preventing them from understanding and sympathising with the true feelings of the people. One of the most-used devices was 'paradiastole', the figure which Quentin Skinner has seen at the heart of Renaissance theories of rhetoric. The figure involves one side accepting the terms but inverting the purpose and values of the other. Both Catholics and Protestants liked to compare contemporary England to late republican Rome, arguing that 'some of the same moral and political effects that had been wrought on the republic of ancient Rome by the increasingly vicious factional fighting between nobiles and populares being visited upon the monarchy of Elizabethan England by the forces of confessional and dynastic conflict'. Both government propagandists and critics reached for this analogy and diagnosed the identical problem but blamed the other faction for destroying the body politic 'with precisely equal certitude, moral passion, and rhetorical force' (p. 85).

Among the most compelling analysis in Bad Queen Bess? centres around the well-known texts written in response to the Anjou match. Professor Lake does a wonderful job in showing how the treatises in question, in particular John Stubbs' Discovery of a gaping gulf, elevated the familiar language of counsel and the duty of morally upright and politically informed citizens to advise the monarch to 'a formal legal, even constitutional form', in demanding 'that the queen not embark on any matrimonial course without the full knowledge, counsel, and consent of parliament' (p. 102). What looks like a political transformation, or a legal codification of a traditional constitutional arrangement finally sorting out the balance of monarch and representative assembly, was as much precipitated by religious crisis as by political theory and practice, which is why we need to read so carefully between the lines if we want to uncover the truth. Therefore, Stubbs had to convince his readers that he was not yet another 'religious engagé', but a concerned citizen eager to make the government work properly for the defence of the queen's subjects. Accordingly his treatise argued that there was not a Catholic, Marian threat to 'the stability of the Elizabethan regime and the autonomy of England' (p. 108) so that he could appeal to as wide a range of readers as possible in order to create a consensus against that (unstated) threat. The same can be said of Lord Henry Howard's opposing Catholic argument, which circulated in manuscript, as he also adopted arguments based on policy, dynastic security, and sound policy, religion only entering the fray in his denunciation of sectarian puritans who were eager to destabilize the country. Religion was all but absent in a debate that was really all about religion.

There is also an enjoyable extensive analysis of the Catholic libel, Leicester's Commonwealth, the important work which took on where the tracts denouncing the 'Regnum Cecilianum' left off. Both, of course, lie behind so much Anti-Stratfordian argument today, bolstering the claim that the real Shakespeare was an oldfashioned loyalist who used his plays to denounce the upstart courtiers who had led the good queen astray and so persuade her to return to the path of righteousness. As Professor Lake points out, for his critics 'the key to Cecil's character and career lay in his social origins, which, like those of his partners in crime, were humble' (pp. 343-4). The libel argued that Mary Stuart had always planned to make her realms havens of liberty encouraging religious toleration, but she had been thwarted by evil counsellors. Elizabeth would - or 
should - put similar policies in place if only she could see the true loyalty of her Catholic subjects and escape from the clutches of the arch-traitor, Robert Dudley.

The case made by Burghley and Leicester was, as might be expected, the mirror image of that in the Catholic Libels:

\begin{abstract}
It sought to protect and foster the godly, and increasingly to exclude a certain sort of Catholic from positions of real influence and power, and, where possible, to foster various Puritan schemes for further reformation. It sought definitively to remove the prospect of a Marian succession and thus render the Protestant revolution effected in 1559 and the ensuing decades permanent. And if that meant intervention in the Low Countries and war with Spain, that was a price worth paying (p. 189).
\end{abstract}

Cecil was thought to have invented a new form of commonwealth, one which entrusted power 'to the basest disciples of Calvin and Machiavelli' (p. 349), running the state at the expense of the ancient moral forces of proper order, the bishops, magistrates and counsellors. Against this was pitched by the militant Catholic case of Robert Parsons, but also the 'Catholic loyalist cause', all three political positions bolstered by a political discourse which was shared by all parties with specific twists. The Catholic loyalist cause argued that toleration for Catholics would inspire loyalty band so build a larger public of supporters of the regime, not, as in the Burghley/Leicester case, a bigger nest of snakes in the grass. As Professor Lake acknowledges, given the reality of so many wavering, disaffected but essentially loyal Catholics, this was a view which built on an 'aspect of contemporary reality' (p. 190) and might well have been a better course to follow than trying to incorporate hostile puritans. Certainly many of the major Catholic families - the Howards and the Cornwallises are mentioned - would have welcomed the chance to preserve their estates and position on society.

Such logic was unlikely to have persuaded the desperate would-be assassin William Parry, who was executed on 2 March 1585. Professor Lake is once again at his astute best in showing how Parry was not simply a lone wolf but that he 'remained trapped within the mental and moral universe of Leicester's Commonwealth' (p. 192), convinced that an inner circle of evil counsellors had so poisoned the mind of the queen that there was no hope of her recovery and, in order to secure any sort of future for English Catholics, she had to die. Other Catholic writers delved further back in time to explain their current misery. Nicholas Sander in his influential assault on the motives for the English Reformation provided a damning analysis of Henry VIII's character. The English king was a man of strong Catholic faith and had the capacity for virtue. However, he was easily led and not very good at reining in his appetites so that, as a result, his court had become a den of vice. Henry foolishly got rid of his true wife and took up with the Protestant whore, Anne Boleyn, who was in fact his own daughter, so it was little wonder that their union produced only shapeless masses of flesh, a sign of God's righteous wrath. Sander was clear that Henry's lapse into heresy and schism was not the result of religious conviction but 'for no other reason in the world than that which came from his lust and wickedness' (cited on p. 259). Accordingly, it should be easy enough for England to return to the fold if only there was a concerted will to do so. The logic follows that of so much political discourse of the period even if it has a certain twist: Henry would have remained Catholic had he been surrounded by better advisers who had been in control of his codpiece. Cardinal Allen made a similar case against Elizabeth, representing her as an equal partner in crime with her lover, the earl of Leicester, a manoeuvre that collapsed the distinction between the queen's two bodies. Throughout the book Professor Lake shows that, then as now, moderation and loyalism were as much 'tactical moves' as sincerely held positions, adopted 'according to the polemical and political demands of the moment' (p. 411). His concluding sentence is surely right and, after such a diligent trawl through the evidence, it is hard not to agree that 'for all their lies, exaggerations, and distortions, the Catholic secret histories give us a better sense of just what was at stake [in late Elizabethan political arguments] ... than the accounts provided by Elizabethan insiders reporting on their own practice or by the many later historians, overly influenced by such claims' (p. 483).

Bad Queen Bess? is an important intervention in significant debates about the past and how we should read 
it, as well as a work of historical astuteness, not least because its author is prepared to do the hard graft of reading material which is sometimes dense and difficult and sometimes misleadingly banal. He has a particular gift for piecing together evidence which has been missed in plain sight so that it finally starts to make sense. If the book has a fault, it is probably rather too long, and some of the less original sections might have been produced in rather briefer form. The author apologises for his style but it is generally lively and forceful, albeit sometimes contained in rather extended sentences. Bad Queen Bess? effectively places debate and division at the heart of the Reformation experience. Professor Lake has no time for the Polyannaish sentiments of a Cavalier critic like Debra Shuger, eager to believe that Christendom was one happy family with shared values so that when the queen got cross about libel or executed a few people it was because the silly fools jolly well deserved it. This book should silence such voices for ever but, like official Protestants and oppositional Catholics, they will probably continue to sow confusion.

\section{Other reviews:}

Times Higher Education

https://www.timeshighereducation.com/books/review-bad-queen-bess-peter-lake-oxford-university-press [2] London Review of Books

https://www.lrb.co.uk/v38/n22/stephen-alford/on-a-par-with-nixon [3]

Source URL:https://reviews.history.ac.uk/review/2083

\section{Links}

[1] https://reviews.history.ac.uk/item/256927 [2] https://www.timeshighereducation.com/books/review-badqueen-bess-peter-lake-oxford-university-press [3] https://www.lrb.co.uk/v38/n22/stephen-alford/on-a-parwith-nixon 